\title{
Structure and genetic variability of the Mexican Sardo Negro breed
}

\section{Joel Domínguez-Viveros ${ }^{1 *}$ (D) Antonio Reyes-Cerón ${ }^{2}$ Juan Fernando Saiz-Pineda ${ }^{2}$ Cesar Villegas-Gutiérrez ${ }^{2}$ Guadalupe Nelson Aguilar-Palma ${ }^{1}$ (D) Felipe Alonso Rodríguez-Almeida ${ }^{1}$ (iD}

${ }^{1}$ Facultad de Zootecnia y Ecología, Universidad Autónoma de Chihuahua, 31453, Chihuahua, México. E-mail: jodominguez@uach.mx. ${ }^{*}$ Corresponding autor.

${ }^{2}$ Asociación Mexicana de Criadores de Cebú. Tampico, Tamaulipas, México.

ABSTRACT: This study analyzed the Sardo Negro breed pedigree (41,521 animals registered from 1958 to 2019) to determine its structure, evolution, and genetic variability (GV). The population genetic parameters evaluated were effective number of founders ( $f$ e) and ancestors (fa), pedigree integrity, additive genetic relationship (AGR); number of complete generations (NCG), maximum generations traced (NMGT), and equivalent complete generations (NECG); effective population size (Ne), inbreeding coefficient (F), and generation interval (GI). The average GI was 7.45 years. A total of 7,804 founders and 4,856 ancestors were identified for a fe of 185 and a fa of 97. The average and maximum values of NCG, NECG, and NMGT were 1.6 and 5.0, 2.5 and 6.5, 4.3 and 12, with Ne estimates of 15.9, 25.9, and 69.0, respectively. The increase in F, linked to Ne, ranged from $0.72 \%$ to $3.1 \%$ per generation. The average values for $F$ and AGR were $3.6 \%$ and $1.0 \%$, respectively. The proportion of inbred individuals was $32.0 \%$, with $F$ values ranging from 0.01 to $62.2 \%$ and an average of $11.3 \%$. The rate of inbred population was $1.3 \%$ per year. The annual rate of AGR was $0.04 \%$. For the continuity and projection of the breed, the evolution of $F$ as a function of Ne and the possible implications of the selection schemes must be considered. The genetic variability sustained over time results from the Ne. Key words: pedigree, inbreeding, tropical livestock, generation interval, Bos indicus.

Análise da estrutura e variabilidade genética da raça Sardo Negro do México

RESUMO: Os objetivos deste estudo foram analisar o pedigree (41.521 registros de 1958 a 2019) da raça Sardo Negro para avaliar a estrutura, evolução e variabilidade genética (VG) da população. Os parâmetros genéticos populacionais utilizados foram: número efetivo de fundadores (fe) e ancestrais (fa); integridade do pedigree; relação genética aditiva (RGA); número de gerações completas (NGC), máximo plotado (NGT) e equivalentes (NGE); tamanho efetivo (Ne); consanguinidade (F); intervalo geracional (IG). O IG médio foi de 7,45 anos. Foram identificados 7.804 fundadores e 4.856 ancestrais, para fe 185 e 97 na fa. As médias e máximas para NGC, NGE e NGT foram 1,6 e 5,0, 2,5 e 6,5, 4,3 e 12, com estimativas de Ne 15,9, 25,9 e 69,0, respectivamente. O aumento de F, vinculado ao Ne, ficou na faixa de 0,72\% a 3,1\% por geração. A média para $F 3,6 \%$ e 1,0\% em $R G A$; a proporção de consanguíneos foi de 32,0\%, com $F$ na faixa de 0,01 a $62,2 \%$ e média de 11,3\%. A taxa da população consanguínea foi de 1,3\% ao ano. No RGA, a taxa ao ano era de 0,04\%. Para a continuidade e projeção da raça, deve-se considerar a evolução de F em função de Ne e as possíveis implicações dos esquemas de seleção. A variabilidade genética sustentada ao longo do tempo resulta do Ne.

Palavras-chave: pedigree, consangüinidade, pecuária tropical, intervalo geracional, Bos indicus.

\section{INTRODUCTION}

Zebu cattle arrived in Mexico in 1883, when the first Zebu bulls were acquired from New Orleans, USA, and introduced to Chihuahua, Mexico. In 1884, Zebu cattle from Brazil entered Mexico; these animals were distributed to the Gulf of Mexico tropical region. Later, in the 1930s, Brazil exported to Mexico and the USA Bos indicus cattle (VIZCARRA, 1975; SANDERS, 1980; HERNÁNDEZ, 2001). In the Zebu lineage populations of the Gulf of Mexico tropical regions, a group of farmers used Gyr and Indubrasil bulls and obtained animals with black and white fur that were initially registered as Gyr in the genealogical records. The first Sardo Negro specimens appeared at the end of the 1940s and the 1950s. In 1976, a population with its own characteristics and a defined breeding pattern (AMCC, 2011) was recognized as an independent breed and removed from the Gyr genealogical record. In January 1978, the Asociación Mexicana de Criadores de Cebú (AMCC) approved the opening of the Sardo Negro genealogical record (BELK, 2017).

The AMCC was formed in 1962 with the aim of grouping the breeders of zebu breeds, 
their derivatives, and their crosses. The AMCC coordinates and controls the genealogical record, breeding pattern, and productive data records of Zebu cattle populations. This association also designs and develop breeding programs (DOMÍNGUEZVIVEROS \& RODRÍGUEZ-ALMEIDA， 2018; AMCC, 2019). Breeding patterns are breed specific; they define the inclusion or exclusion criteria of individuals applying for registration (AMCC, 2011). The recorded genealogical information conforms the pedigree of the entire population; its main functions are to ensure breed purity, support conservation and breeding programs, and provide a unique and permanent identification of each of the animals in their system (CONARGEN, 2010; AMCC, 2019).

The study of the genetic variability is the basis for the establishment and development of selection and/or conservation programs. Demographic studies allow describing the structure and dynamics of individuals in populations, while genetic studies allow analyzing the variability and genetic evolution of individuals in populations. Pedigree analysis is an important tool for describing genetic variability and its evolution through generations. (GUTIÉRREZ et al. 2003). This study analyzed the pedigree of the Sardo Negro breed to identify the founding ancestors and evaluate the structure, evolution, and genetic variability of the population.

\section{MATERIALS AND METHODS}

The Sardo Negro genealogical registry database, provided by the AMCC, was analyzed. The pedigree included 41,521 animals born from 1958 to 2019. The pedigree analysis was carried out using the Endog software (GUTIÉRREZ \& GOYACHE, 2005); the evaluated population genetic parameters were:

Effective number of founders (fe) and ancestors (fa). A founder is defined as any animal with unknown parents. The fe refers to the number of founders that would produce the existing genetic diversity in the population by contributing in equal measure. An ancestor is any animal, founder or not, that has contributed to the genetic variability of the population. The fa was defined as the number of ancestors required to explain the total genetic variability of the population (RUÍZ-FLORES et al., 2006; NÚÑ̃EZ-DOMÍNGUEZ et al. 2020).

Pedigree integrity (PI) and additive genetic relationship (AGR). PI, as the proportion of known ancestors up to the fifth generation; in addition to the number of complete generations (NCG), maximum generations traced (MGT), and equivalent complete generations (ECG). The AGR was determined from the matrix of additive genetic relationships between all the pedigree individuals. The calculation corresponds to the average value of the coefficients of each individual with the rest of the pedigree (GUTIÉRREZ et al., 2003; OCAMPO et al., 2020).

Effective population size $(\mathrm{Ne})$ and inbreeding coefficient (F). The $\mathrm{Ne}$ defines the number of breeders that could generate the calculated inbreeding and change rate in the genetic variance under the ideal population scheme; it was estimated through three approaches: NCG, MGT, and ECG (GUTIÉRREZ et al., 2008; GUTIÉRREZ et al., 2009). The F, proportion of inbred individuals and average values, of each individual was estimated. Time trends were generated using the year of birth (FALCONER \& MACKAY, 1996; PEIXOTO et al., 2010).

Generation interval (GI). The GI was determined using the mean age of a reproductive animal, at which it is replaced by one of its offspring. The GI was calculated using the four selection paths: father - son, father - daughter, mother - son, and mother - daughter (RAMÍREZ-VALVERDE et al., 2018; HAGAN \& CUE, 2019). Based on the GI calculations, the period that includes the analyzed information was divided into generations. The proportion of individuals selected as breeders was analyzed, and an $\mathrm{Ne}$ was obtained [ $\left(4^{*}\right.$ bulls * mothers) / (bulls + mothers)].

\section{RESULTS AND DISCUSSION}

Sardo Negro was developed in the Mexican tropic; the evaluated herds are distributed in the Gulf of Mexico and Yucatán peninsula regions, as well as in the States of Oaxaca and Chiapas. The pedigree derived from 1,124 bulls and 12,849 cows. The average number of calves per bull and cow was 30.1 and 2.6, respectively. Table 1 shows the GI results, the selection pressure indicators, and the Ne across six generations. Generation zero groups founders born in 1980 or earlier; generations one to four correspond to individuals born after 1981, in eight-year periods each one; generation five grouped individuals born after 2013. During breed formation, animals from generations one and two can be attributed to the two inter set crosses required to stabilize the individual and maternal heterosis.

The GI is important to validate losses of genetic variability and genetic advancement over time; the intensity of selection tends to reduce the GI, but results in losses of genetic variability given the little contribution of the reproducers (GUTIÉRREZ 
Table 1 - Results for selection pressure, effective population size (Ne), and generation interval in the pedigree of Sardo Negro cattle.

\begin{tabular}{|c|c|c|c|c|c|}
\hline \multirow[t]{2}{*}{ Gen } & \multicolumn{2}{|c|}{------------Selection pressuere $\dagger$---------- } & \multirow[t]{2}{*}{$\mathrm{Ne}$} & \multicolumn{2}{|c|}{-----------------Generation interval--------------- } \\
\hline & Males & Females & & Line selection & years \pm ee \\
\hline G0 & 56.0 & 43.4 & 553.7 & Father - son & $7.7 \pm 0.15$ \\
\hline G1 & 12.5 & 33.4 & 393.8 & Father - daughter & $7.2 \pm 0.14$ \\
\hline $\mathrm{G} 2$ & 8.6 & 27.3 & 621.5 & Mother - son & $7.5 \pm 0.12$ \\
\hline G3 & 6.2 & 28.2 & 962.6 & Mother - daughter & $7.4 \pm 0.13$ \\
\hline G4 & 5.6 & 42.3 & 1188.0 & & \\
\hline G5 & 2.5 & 87.2 & 385.1 & & \\
\hline
\end{tabular}

†Within generation, percentage of animals selected as bulls and mother cows, based on the total number of available males and females. Gen, generations: G0, generation zero or initial, corresponds to the founders born in 1980 or earlier; G1, born from 1981 to 1988; G2, from 1989 to 1996; G3, from 1997 to 2004; G4, from 2005 to 2012; G5, born after 2013. se, standard error.

et al., 2008). The proportion of animals (generations one through four) selected as breeders with at least one registered offspring ranges from 5.6 to $12.5 \%$ in males and from 27.3 to $42.3 \%$ in females (Table 1); this is an indicator of the selection pressure exerted by the breeders.

A total of 7,804 animals were identified as founders and 4,856 as ancestors, with a fa and fe of 185 and 97, respectively. Figure 1 shows the evolution of the number of ancestors and the percentage of genetic variability in the pedigree, where the initial value corresponds to the $5.5 \%$ explained by the ancestor with the highest contributions. Subsequently, 48 ancestors explain the $50 \%$ and 2,470 the $95 \%$. Figure 2 shows the relationship between PI and the proportion of known ancestors across five generations. The percentage of individuals with unknown parents is attributed to those identified as founders; however, the genealogical information or PI of paternal lines is more complete. The current genealogical registry requires at least three ancestor generations to issue a registry certificate (AMCC, 2019). The average and maximum values of NCG, ECG, and MGT were 1.6 and 5.0, 2.5 and 6.5, 4.3 and 12, respectively, with $\mathrm{Ne}$ estimates of 15.9, 25.9, and 69.0, respectively. The increase in $\mathrm{F}\left(\Delta \mathrm{F}=1 /\left(2^{*} \mathrm{Ne}\right)\right)$ linked to estimates of

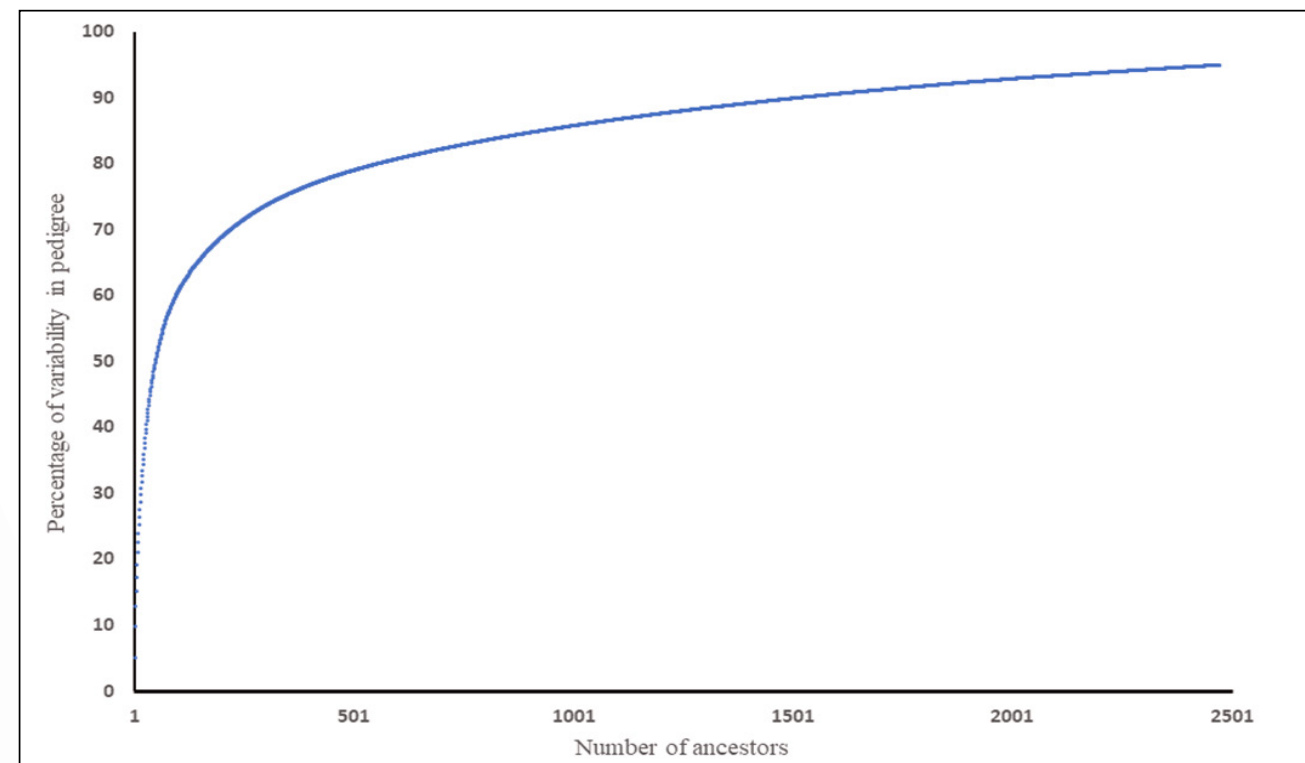

Figure 1 - Evolution of percentage of genetic variability in the pedigree based on the numbers of ancestors 


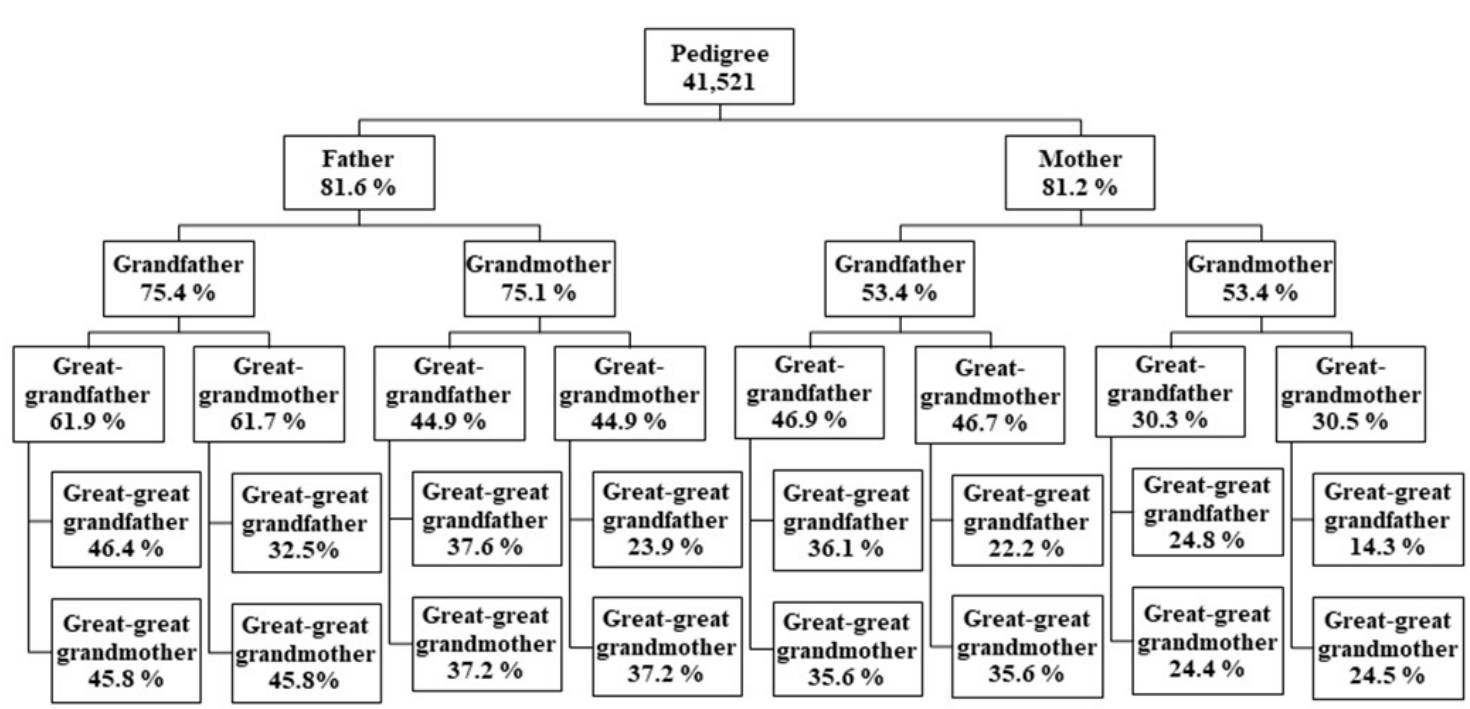

Figure 2 - Evolution of pedigree integrity based on the proportion of known ancestors across five generations

the Ne ranged from $0.72 \%$ to $3.1 \%$ per generation. The average values for $\mathrm{F}$ and AGR were $3.6 \%$ and $1.0 \%$, respectively. However, the proportion of inbred individuals was $32.0 \%$, with $\mathrm{F}$ values ranging from 0.01 to $62.2 \%$ and an average of $11.3 \%$.

Figure 3 represents the evolution of the inbred population and the inbreeding levels over time. The first inbred animals appeared in 1981, and the growth rate of the inbred population was $1.3 \%(\mathrm{p}<0.05)$ per year. Figure 4 shows the evolution of the AGR levels; the change rate per year was $0.04 \%(\mathrm{p}<0.05)$. The $\mathrm{F}$ rate shows the loss of genetic variability during the breed formation and development processes. Results in figures 3 and 4 (low magnitude increases in the proportion of inbred animals and low levels of AGR) can be associated with an adequate number of breeders with low kinship levels. However, for the continuity and projection of the breed, the evolution of $\mathrm{F}$ as a function of $\mathrm{Ne}$ and the possible implications of the selection schemes must be considered. The genetic variability sustained over time results from the Ne. For the population projection, $\mathrm{F}$ increases below $1 \%$ are recommended, which require a $\mathrm{Ne}$ greater than 50 (FAO, 1998). The selection based on Best Linear Unbiased Prediction (BLUP), which results from the genetic evaluations carried out in Sardo Negro (DOMÍNGUEZ-VIVEROS \& RODRÍGUEZ-ALMEIDA, 2018), favor the selection of related animals, and thus, increase inbreeding (WU \& SCHAEFFER, 2000; WEIGEL, 2001).

For comparison and discussion purposes, in the Mexican tropic, the Tropicarne, Romosinuano, and Tropical Dairy Criollo cattle have developed alternately to Sardo Negro, with population parameters that differ from those observed in this study. In Tropicarne (Mexican synthetic breed), the genealogical information dates from 1960. The first inbred animal appeared in 1976; seven individuals explained $50 \%$ of the pedigree variability; $52 \%$ of the population was inbred, with an average and maximum value of $3.6 \%$ and $38.7 \%$, respectively. The fe and fa estimates were 48 and 20; the average values of MGT, NCG, and ECG were 4.83, 2.19, and 3.19, respectively (RUÍZ-FLORES et al., 2006). The differences in the development of the Tropicarne and Sardo Negro breeds can be attributed to the pedigree depth, given the average number of known generations in the three modalities and the fe and fa estimates that result from the size of the basal or founder population.

A study (NÚÑEZ-DOMÍNGUEZ et al. 2020) of three Romosinuano reference populations (pure) with genealogical information since 1953 reported $\mathrm{Ne}$, fe, and fa estimates ranging from 34.9 to $47.7,50$ to 59 , and 24 to 30 , respectively; the GI values fluctuated from 5.59 to 8.98 years, with an 


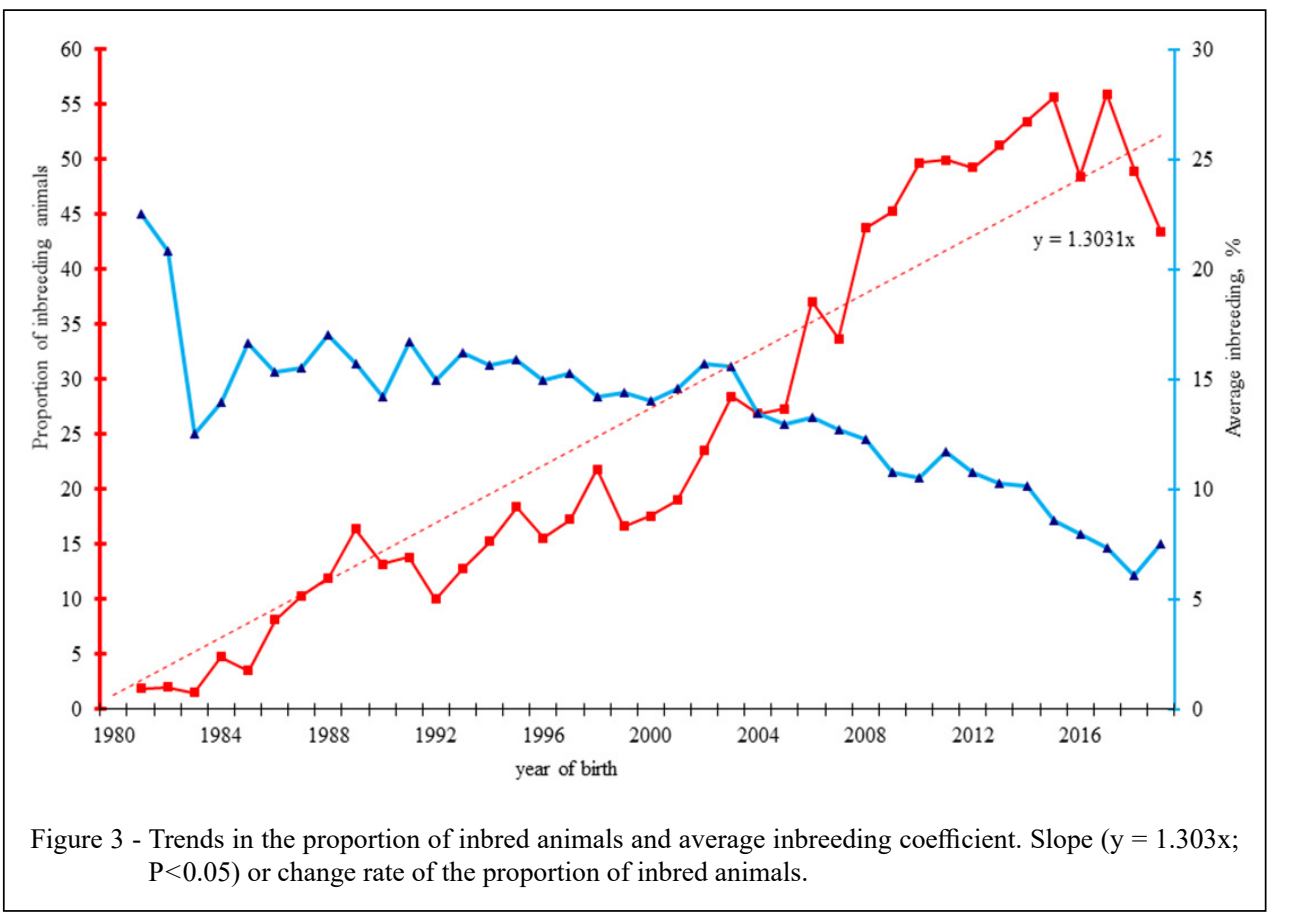

average of 6.8 years; nine ancestors explained $50 \%$ of the pedigree variability, the ancestor with the highest contribution explained $10.3 \%$; and the average $\mathrm{MCG}$, NCG, and ECG fluctuated from 5.2 to 8.8, from 0.47 to 1.56 , and from 1.8 to 3.3 , respectively. In Tropical Dairy Criollo cattle, pedigree information dates from
1950, and the fe, fa, and Ne estimates were 111, 72, and 68.1, respectively. Additionally, the average GI, F, and AGR values were 7.0 years, $1.07 \%$, and $1.19 \%$ (ROSENDO et al., 2018). The Romosinuano and Tropical Dairy Criollo breeds develop in the Mexican tropic as a genetic resource in pure populations or

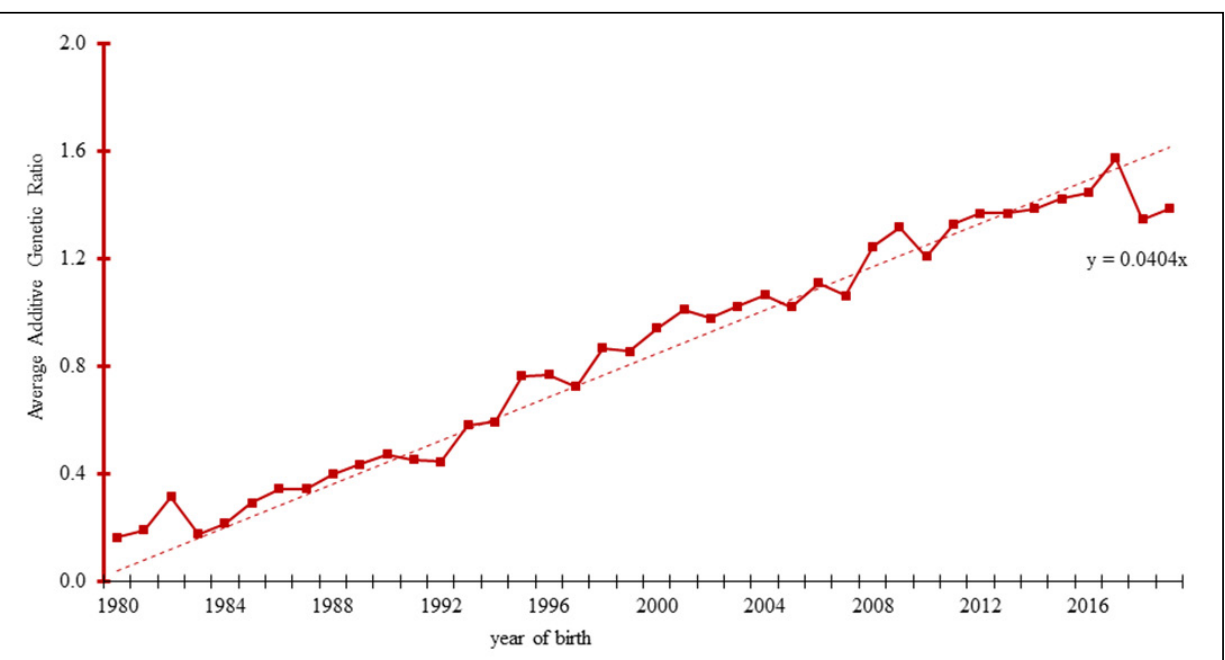

Figure 4 - Trends and change rate $(y=0.0404 x ; P<0.05)$ of the additive genetic relationship over time. 
breeding schemes. The differences in the population parameters of Sardo Negro can be attributed to the $\mathrm{Ne}$ fluctuation associated with fe and fa, or to variability losses due to bottleneck effects.

Sardo Negro is associated with Zebu cattle populations, given the breeds that comprise it and the adaptation and productivity traits in tropical regions. Santana et al. (2016) analyzed the structure and genetic diversity of seven Zebu breeds. Their results expressed the evolution of the populations and possible effects due to BLUP-based selection: the average fe was 119.3, with values ranging from 37 (Nelore) to 281.9 (Brahman); the average fa was 47.3, with values ranging from 26.9 (Sindi) to 69.9 (Guzerat); average F values ranged from 1.9\% (Tabapua) to $6.2 \%$ (Indubrasil); the percentage of inbred individuals fluctuated from 59.7 (Sindi) to 88.8 (Guzerat). Regarding GI (years), the average values ranged from 6.95 (Brahman) to 9.78 (Indubrasil), with an overall average of 7.9; the maximum MGT values fluctuated from 13 (Sindi) to 30 (Brahman), with an average of 18.5; the ECG average value ranged from 4.8 (Sindi) to 7.2 (Brahman), the overall mean was 5.74. Associated with the results published for Nelore, Guzerat, Gyr, and Brahman cattle, other research groups (VOZZI et al., 2006; FARIA et al., 2009; FARIA et al., 2010; PEIXOTO et al., 2010; CAVANI et al., 2018) defined the population parameters and traits of the Zebu populations. The Sardo Negro results fell within the Zebu cattle context, showed the evolution and development of the breed, and provided information for its future projection.

Regarding indigenous populations, a previous study reported higher percentages of known ancestors in five South African breeds (ABIN et al., 2016). For GI (years), the average value within breed ranged from 6.0 to 6.4 ; the average $\mathrm{Ne}$ value was 174.6 , with values ranging from 89 to 364 ; the $F$ rate per generation ranged from 0.14 to 0.56 , with an average of 0.368. Chiara et al. (2019) studied six Italian breeds and reported Ne values ranging from 14.62 to 39.79 , with an average value of 21.36. Regarding F increases, the average value was 2.59 , with values ranging from $1.26 \%$ to $3.42 \%$ per generation. Average F and AGR ranged from 1.23 to 7.25 and from 0.04 to 10.54 , respectively. Within the breed, the average GI ranged from 7.8 to 12.5 years. The average ECG, NCG, and MGT values ranged from 0.75 to $3.91,0.45$ to 2.44 , and 1.20 to 7.55 , respectively. Moreover, in the genetic structure analysis of seven Spanish breeds subjected to BLUP-based selection schemes and pedigree integrity higher than Sardo Negro, the authors (CAÑASÁLVAREZ et al., 2014) reported Ne values ranging from 40 to 408, based on MGT and Ne values ranging from 12 to 58 and from 18 to 85 based on NCG and ECG, respectively. The proportion of inbred animals fluctuated from 2.5 to 95 , and all populations showed positive trends in their F levels. The average GI per breed ranged from 5.4 to 7.06 years. Regardless of the contrasting production systems and environment, the differences with Sardo Negro, as an indigenous Mexican breed, are attributed to breeding schemes (Spain and South Africa) that impact the selection response (reduction of the GI), conserving the $\mathrm{Ne}$ and genetic variability. These differences could also be attributed (FABBRI et al., 2019) to the reduced number of founders and ancestors and breeding schemes mainly focused on conservation.

\section{CONCLUSION}

These results summarized previous breeding practices and anticipated the relationship between the selection response and increases in inbreeding, representing useful information for designing breeding programs. The pedigree analysis of the newly created breed Sardo Negro helped identifying the founding ancestors and percentage contributions to pedigree variability. The percentage of known ancestors and the number of known generations indicated good pedigree integrity and genealogical information content. We quantified the inbred population's evolution and their additive genetic relationships as indicators of the possible loss of variability.

\section{ACKNOWLEDGMENTS}

To the Asociación Mexicana de Criadores de Ganado Cebú for providing the genealogical information analyzed in this study within the framework of the collaborative project with, the Universidad Autónoma de Chihuahua and the Consejo Nacional de los Recursos Genéticos Pecuarios.

\section{DECLARATION OF CONFLICT OF INTEREST}

The authors declare no conflict of interest.

\section{AUTHORS' CONTRIBUTIONS}

All authors contributed equally for the conception and writing of the manuscript. All authors critically revised the manuscript and approved of the final version.

\section{REFERENCES}

ABIN, S. et al. Population structure and genetic trends for indigenous African beef cattle breeds in South Africa. South 
Africa Journal of Animal Science, v.46:e2, 2016. Available from: $<$ https://www.ajol.info/index.php/sajas/article/view/137700>. Accessed: Feb. 10, 2021. doi: 10.4314/sajas.v46i2.5.

AMCC. Patrón racial de bovinos Sardo Negro. Asociación Mexicana de Criadores de Cebú. Tampico, Tamaulipas, México. 2011.

AMCC. Reglamento técnico. Asociación Mexicana de Criadores de Cebú. Tampico, Tamaulipas, México. 2019.

BELK, T. Los orígenes de la raza Sardo Negro. Revista Cebú Mexicano, v.34, p.27-32, 2017. Available from: $<$ https://www.cebumexicano.com/ articulo.php?uid=MzQx $>$. Accessed: August 17, 2021.

CAÑAS-ÁLVAREZ, J.J. et al. Monitoring changes in the demographic and genealogical structure of the main Spanish local beef breeds. Journal of Animal Science, v.92, p.4364-4374, 2014. Available from: <https://academic.oup.com/jas/articleabstract/92/10/4364/4702670>. Accessed: Feb. 10, 2021. doi: $10.2527 /$ jas. $2013-7420$.

CAVANI, L. et al. Genetic diversity of Brazilian Brahman cattle by pedigree analysis. Pequisa Agropecuaria Brasileira, v.53, p.7479, 2018. Available from: <https://seer.sct.embrapa.br/index.php/ pab/article/view/25118>. Accessed: Feb. 10, 2021. doi: 10.1590/ s0100-204x2018000100008.

CONARGEN. Guía técnica de programas de control de producción y mejoramiento genético en bovinos. Consejo Nacional de los Recursos Genéticos Pecuarios. México. 2010.

DOMÍNGUEZ-VIVEROS J.; RODRÍGUEZ-ALMEIDA F.A. Resumen de evaluaciones genéticas en bovinos Cebú de México 2018. Asociación Mexicana de Criadores de Cebú. Editado por la Universidad Autónoma de Chihuahua. Chihuahua, México. 2018. Available from: <https://cebumexico.com/wp-content/ uploads/2021/06/Catalogo-Bovinos-Cebu-Agosto2018.pdf $>$. Accessed: Aug. 17, 2021.

FABBRI, M. C. et al. Population structure and genetic diversity of Italian beef breeds as a tool for planning conservation and selection strategies. Animals, 9e880, 2019. Available from: <https://www. mdpi.com/2076-2615/9/11/880>. Accessed: Feb. 10, 2021. doi: 10.3390/ani9110880.

FALCONER, D.S.; MACKAY, T.F.C. Introducción a la genética cuantitativa. Editorial Acribia. Zaragoza, España. 1996.

FAO. Secondary guidelines for development of national farm animal genetic resources management plans: Management of small populations at risk. Food and Agriculture Organization for the United Nations. Rome, Italy. 1998. <http://www.fao.org/ documents/card/es/c/d074fc39-aca0-58ab-8024-beaf80ba6014/>. Accessed: Aug. 17, 2021.

FARIA, F. J. C. et al. Pedigree analysis in the Brazilian Zebu breeds. Journal of Animal Breeding Genetics, v.126, p.148-153, 2009. Available from: $<$ https://onlinelibrary.wiley.com/doi/abs/10 $.1111 /$ j.1439-0388.2008.00767.x>. Accessed: Feb. 10, 2021. Doi: 10.1111/j.1439-0388.2008.00767.x.

FARIA, L. C. et al. Variabilidade genética de raça Brahman no Brasil detectada por meio de análise de pedigree. Pesquisa Agropecuária Brasileira, v.45, p.1133-1140, 2010. Available from: <http:// dx.doi.org/10.1590/S0100-204X2010001000012>. Accessed: Feb. 10, 2021. doi: 10.1590/S0100-204X2010001000012.
GUTIÉRREZ, J. P. et al. Pedigree analysis of eight Spanish beef cattle breeds. Genetics Selection Evolution, v.35, p.43-63, 2003. Available from: <https://www.gse-journal.org/articles/gse/ abs/2003/01/g350103/g350103.html>. Accessed: Feb. 10, 2021. Doi: $10.1051 /$ gse:2002035.

GUTIÉRREZ, J. P; GOYACHE, F. A note on ENDOG: a computer program for analysis pedigri information. Journal of Animal Breeding and Genetics, v.122, p.172-176, 2005. Available from: <https://onlinelibrary.wiley.com/doi/abs/10.11 11/j.1439-0388.2005.00512.x>. Accessed: Feb. 10, 2021. doi: 10.1111/j.1439-0388.2005.00512.x.

GUTIÉRREZ, J. P. et al. Individual increase in inbreeding allows estimating realized effective sizes from pedigrees. Genetics Selection Evolutions, v.40, p.359-378, 2008. Available from: $<$ https://www.gse-journal.org/articles/gse/abs/2008/04/g07044/ g07044.html>.Accessed: Feb. 10, 2021. doi: 10.1051/gse:2008008.

GUTIÉRREZ, J. P. et al. Improving the estimation of realized effective population sizes in farm animals. Journal of Animal Breeding and Genetics, v.126, p.327-332, 2009. Available from: <https://onlinelibrary.wiley.com/doi/abs/10.11 11/j.1439-0388.2009.00810.x>. Accessed: Feb. 10, 2021. doi: 10.1111/j.1439-0388.2009.00810.x.

HAGAN, B. A.; CUE, R. Generation intervals in Canadian dairy cattle herds. Canadian Journal of Animal Science, v.100, p.175183, 2019. Available from: <https://cdnsciencepub.com/doi/ abs/10.1139/CJAS-2019-0053>. Accessed: Feb. 10, 2021. Doi: 10.1139/cjas-2019-0053.

HERNÁNDEZ, L. Historia ambiental de la ganadería en México. Instituto de Ecologia. Xalapa, Veracruz, México. 2001.

NÚÑEZ-DOMÍNGUEZ, R. et al. Evaluation of the Romosinuano cattle population structure in Mexico using pedigree analysis. Revista Colombiana de Ciencias Pecuarias, v.33, p.44-59, 2020. Available from: <https://revistas.udea.edu.co/index.php/rccp/ article/view/338067>. Accessed: Feb. 10, 2021. doi: 10.17533/ udea.rccp.v32n4a05.

OCAMPO, G. R. et al. Genetic diversity assessed by pedigree analysis in the Blanco Orejinegro (BON) cattle breed population from the Colombian germplasm bank. Chilean Journal Agriculture Animal Science, v.36, p.69-77, 2020. Available from: $<$ http://revistas.udec.cl/index.php/chjaas/article/view/1958>. Accessed: Feb. 10, 2021. doi: 10.29393/chjaas36-4d30004>.

PEIXOTO, M.G.C.D. et al. Genetic basis and inbreeding in the Brazilian Guzerat (Bos indicus) subpopulation selected for milk production. Livestock Science, v.131, p.168-174, 2010. Available from: <https://www.sciencedirect.com/science/article/ abs/pii/S187114131000123X $>$. Accessed: Feb. 10, 2021. doi: 10.1016/j.livsci.2010.03.015>.

RAMÍREZ-VALVERDE, R. et al. Pedigree analysis for determination of genetic diversity in Mexican beef cattle population. Revista Mexicana de Ciencias Pecuarias, v.9, p.614635, 2018. Available from: <https://cienciaspecuarias.inifap.gob. $\mathrm{mx} /$ index.php/Pecuarias/article/view/4654>. Accessed: Feb. 10, 2021. doi: 10.22319/rmcp.v9i4.4654.

ROSENDO, P.A. et al. Genetic variability of Tropical milking criollo cattle of Mexico estimated from genealogy information. Revista Colombiana de Ciencias Pecuarias, v.31, p.196- 
203, 2018. Available from: <https://revistas.udea.edu.co/index. php/rccp/article/view/330534>. Accessed: Feb. 10, 2021. doi: 10.17533/udea.rccp.v31n3a04>.

RUÍZ-FLORES, A. et al. Levels and effects of inbreeding on growth and reproductive traits in Tropicarne and Brown Swiss cattle. Agrociencia, v.40, p.289-301, 2006. Available from: $<$ https://agrociencia-colpos.mx/index.php/agrociencia/article/ view/463>.

SANDERS, J. O. History and development of Zebu cattle in the United States. Journal of Animal Science, v.50, p.1188-1200, 1980. Available from: <https://academic.oup.com/jas/articleabstract/50/6/1188/4662919>. Accessed: Feb. 10, 2021. doi: $10.2527 /$ jas $1980.5061188 \mathrm{x}$.

SANTANA, J. R, M. L. et al. Structure and genetic diversity of Brazilian Zebu breeds assessed by pedigree analysis. Livestock Science, v.187, p.6-15, 2016. Available from: <https://www. sciencedirect.com/science/article/abs/pii/S1871141316300257>. Accessed: Feb. 10, 2021. doi: 10.1016/j.livsci.2016.02.002>.
VIZCARRA, S.O. El Cebú en México. Editorial B. Costa Amic, México. 1975.

VOZZI, P. A. et al. Structure and genetic variability in Nellore (Bos indicus) cattle by pedigree analysis. Genetic and Molecular Biology, v.29, p.482-485, 2006. Available from: <https://doi. org/10.1590/S1415-47572006000300014>. Accessed: Feb. 10, 2021. doi: 10.1590/S1415-47572006000300014.

WEIGEL, K. A. Controlling inbreeding in modern breeding programs. Journal of Dairy Science, v.84, p.177184, 2001. Available from: <https:/www.sciencedirect.com/science/article/ pii/S0022030201702135>. Accessed: Feb. 10, 2021. doi: 10.3168/ jds.S0022-0302(01)70213-5.

WU, L.; SCHAEFFER, R. Reducing the effect of parent averages from animal solution in mixed model equations. Journal Animal Breeding and Genetics, v.117, p.361-374, 2000. Available from: $<$ https://onlinelibrary.wiley.com/doi/abs/10.10 46/j.1439-0388.2000.00242.x>. Accessed: Feb. 10, 2021. doi: 10.1046/j.1439-0388.2000.00242.x>. 